\title{
Feeding practices and nutritional status of HIV-exposed and HIV-unexposed infants in the Western Cape
}

\begin{tabular}{|c|c|}
\hline \multicolumn{2}{|c|}{$\begin{array}{l}\text { Authors: } \\
\text { Magdel E. Rossouw }{ }^{1} \\
\text { Morna Cornell } \\
\text { Mark F. Cotton } \\
\text { Monika M. Esser }\end{array}$} \\
\hline \multicolumn{2}{|c|}{$\begin{array}{l}\text { Affiliations: } \\
{ }^{1} \text { Department of Paediatrics } \\
\text { and Child Health, Family } \\
\text { Clinical Research Unit, } \\
\text { Stellenbosch University, } \\
\text { Tygerberg Campus, } \\
\text { South Africa }\end{array}$} \\
\hline \multicolumn{2}{|c|}{$\begin{array}{l}{ }^{2} \text { School of Public Health and } \\
\text { Family Medicine, University } \\
\text { of Cape Town, South Africa }\end{array}$} \\
\hline \multicolumn{2}{|c|}{$\begin{array}{l}{ }^{3} \text { Department of Pathology, } \\
\text { National Health Laboratory } \\
\text { Service Immunology Unit } \\
\text { (NHLS), Stellenbosch } \\
\text { University, Tygerberg } \\
\text { Campus, South Africa }\end{array}$} \\
\hline \multicolumn{2}{|c|}{$\begin{array}{l}\text { Corresponding author: } \\
\text { Magdel Rossouw, } \\
\text { magdel@sun.ac.za }\end{array}$} \\
\hline \multicolumn{2}{|c|}{$\begin{array}{l}\text { Dates: } \\
\text { Received: } 09 \text { June } 2015 \\
\text { Accepted: } 13 \text { Nov. } 2015 \\
\text { Published: } 13 \text { May } 2016\end{array}$} \\
\hline \multicolumn{2}{|c|}{$\begin{array}{l}\text { How to cite this article: } \\
\text { Rossouw ME, Cornell M, } \\
\text { Cotton MF, Esser MM. } \\
\text { Feeding practices and } \\
\text { nutritional status of } \\
\text { HIV-exposed and HIV- } \\
\text { unexposed infants in the } \\
\text { Western Cape. S Afr J HIV } \\
\text { Med. 2016;17(1), a398. } \\
\text { http://dx.doi.org/10.4102/ } \\
\text { sajhivmed.v17i1.398 }\end{array}$} \\
\hline \multicolumn{2}{|c|}{$\begin{array}{l}\text { Copyright: } \\
\text { (C) 2016. The Authors. } \\
\text { Licensee: AOSIS. This } \\
\text { is licensed under the } \\
\text { Creative Commons } \\
\text { Attribution License. }\end{array}$} \\
\hline \multicolumn{2}{|l|}{ Read online: } \\
\hline 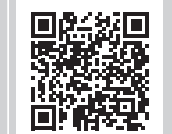 & $\begin{array}{l}\text { Scan this QR } \\
\text { code with your } \\
\text { smart phone or } \\
\text { mobile device } \\
\text { to read online. }\end{array}$ \\
\hline
\end{tabular}

Background: Optimal infant- and young child-feeding practices are crucial for nutritional status, growth, development, health and, ultimately, survival. Human breast milk is optimal nutrition for all infants. Complementary food introduced at the correct age is part of optimal feeding practices. In South Africa, widespread access to antiretrovirals and a programme to prevent mother-to-child transmission of HIV have reduced HIV infection in infants and increased the number of HIV-exposed uninfected (HEU) infants. However, little is known about the feeding practices and nutritional status of HEU and HIV-unexposed (HU) infants.

Objective: To assess the feeding practices and nutritional status of HIV-exposed and HIV-unexposed (HU) infants in the Western Cape.

Design: Prospective substudy on feeding practices nested in a pilot study investigating the innate immune abnormalities in HEU infants compared to HU infants. The main study commenced at week 2 of life with the nutrition component added from 6 months. Information on children's dietary intake was obtained at each visit from the caregiver, mainly the mother. Head circumference, weight and length were recorded at each visit. Data were obtained from 6-, 12- and 18-month visits. World Health Organization feeding practice indicators and nutrition indicators were utilised.

Setting: Tygerberg Academic Hospital, Western Cape. Mothers were recruited from the postnatal wards.

Subjects: Forty-seven mother-infant pairs, $25 \mathrm{HEU}$ and $22 \mathrm{HU}$ infants, participated in this nutritional substudy. Eight (17\%) infants, one HU and seven HEU, were lost to follow-up over the next 12 months. The HEU children were mainly Xhosa (76\%) and HU were mainly mixed race $(77 \%)$.

Results: The participants were from poor socio-economic backgrounds. In both groups, adherence to breastfeeding recommendations was low with suboptimal dietary diversity. We noted a high rate of sugar- and salt-containing snacks given from a young age. The HU group had poorer anthropometric and nutritional indicators not explained by nutritional factors alone. However, alcohol and tobacco use was much higher amongst the HU mothers.

Conclusion: Adherence to breastfeeding recommendations was low. Ethnicity and cultural milieu may have influenced feeding choices and growth. Further research is needed to understand possible reasons for the poorer nutritional and anthropometric indicators in the HU group.

\section{Introduction}

\section{Background}

Observational studies show that exclusive breastfeeding in the early months of life and continued breastfeeding with timely transition to high-quality complementary foods deliver physiological and economic benefits to mothers and maximise nutrient intake, growth, development and survival of children. ${ }^{1,2,3,4,5}$ The World Health Organization (WHO) recommends exclusive breastfeeding for the first 6 months of life. ${ }^{6,7}$ Introduction of fluids other than breast milk is associated with increased morbidity and mortality during the first 6 months of life. $8,9,10$ Complementary foods should be introduced from 6 months. ${ }^{11}$ Continued breastfeeding up to 24 months is advised. ${ }^{11}$

In the absence of interventions, $5 \%-20 \%$ of infants born to HIV-infected mothers acquire HIV through breastfeeding. ${ }^{11}$ Given the need to reduce the risk of HIV transmission, whilst minimising other risks for morbidity and mortality, current WHO guidelines state that when replacement 
feeding is acceptable, feasible, affordable, sustainable, and safe, HIV-infected mothers should avoid breastfeeding completely. ${ }^{11}$ If not feasible, HIV-infected mothers should exclusively breastfeed for the first few months and gradually stop breastfeeding, provided that conditions for replacement feeding are in place. ${ }^{12}$ The 2015 South African national programme to prevent mother-to-child transmission of HIV (PMTCT) supports exclusive breastfeeding for 6 months and continued up to 12 months. Maternal antiretroviral therapy (ART) should continue until the infant is fully weaned. ${ }^{13}$ Formula milk was provided at public health facilities solely for PMTCT until 2013.

Optimal feeding practices are crucial for the nutritional status, health and survival of infants. ${ }^{14}$ Anthropometric measurements are screening tools for assessing nutritional status. The three main indicators used to define undernutrition are as follows: stunting, underweight and wasting. Stunting is associated with repeated exposure to adverse economic conditions, poor sanitation and the interactive effects of poor intake and infection. ${ }^{15,16,17}$ Underweight indicates a history of poor health or nutritional insult, whilst wasting is associated with recent illness and failure to gain weight or a loss of weight. ${ }^{18}$ Knowing the levels of stunting, underweight and wasting is important in determining the overall health of the community. In contexts of high HIV prevalence such as South Africa, it is important to understand how feeding patterns impact on the health of HIV-exposed uninfected children (HEU).

The success of the PMTCT programme has decreased HIV infection in infants, conversely increasing the number of HEU infants. To date, there has been no comparison of feeding practices between HEU and HIV-unexposed (HU) children in the Western Cape. In this study, we explored feeding practices and nutritional status in HEU and HU children over 12 months. Participants had been recruited for a pilot study of innate immune abnormalities in 2009, when antenatal dual ART was provided unless combination ART was indicated in the mother for either WHO stage 3 or 4 disease or a CD 4 count at below 200 cells $/ \mu \mathrm{L} .{ }^{19}$ The aim of the study was to assess the feeding practices and nutritional status of HEU and HU infants.

\section{Methods}

HIV-infected and -uninfected mothers and their infants were recruited from the postnatal maternity wards of Tygerberg Academic Hospital, which serves patients from lower socioeconomic communities in the Western Cape. The aim of the study was to compare infectious disease morbidity and vaccine responses in HEU and HU infants over 24 months. ${ }^{20,21}$ Fifty-five infants, $27 \mathrm{HEU}$ and $28 \mathrm{HU}$, were enrolled at 2 weeks of age in the main study. The prospective substudy on feeding practices commenced in October 2009 after 6 months on study. Five $(9 \%)$ mother-infant pairs, two with HEU infants and three HU, were lost to follow-up over the first 6 months of the main study. Three (5\%) HEU infants became infected and were excluded. Forty-seven mother-infant pairs (85\%), comprising $25 \mathrm{HEU}$ infants and $22 \mathrm{HU}$ infants, participated in this nutritional substudy. Eight (17\%) infants, one HU and seven HEU, were lost to follow-up over the next 12 months. A trained staff nurse consented the mothers for the nutrition study. Data were obtained from 6-, 12- and 18-month visits. A staff nurse and medical professionals conducted the nutritional questionnaire (Appendix 1) at each visit. The Human Research Ethics Committee, Faculty of Medicine and Health Sciences at Stellenbosch University (N08/10/289) approved the study protocol.

Nutritional information was obtained from the caregiver, generally the mother. Weight, length and head circumference were recorded at each visit. Sociodemographic questions were included in the nutrition questionnaire. Caregivers were asked to answer yes or no to questions regarding nonnutritional foods, that is, salty snacks and sugar-containing snacks and drinks, given to the infant and the current alcohol and tobacco (smoking) use of the caregiver (the mother).

We used simple rapid-assessment techniques with the WHO indicators ${ }^{22}$ to assess feeding practices.

\section{World Health Organization indicators ${ }^{22}$}

\section{Early initiation of breastfeeding}

The proportion of children who were put to the breast within 1 hour of birth.

\section{Exclusive breastfeeding under 6 months}

The proportion of infants $0-5$ months of age who were fed exclusively with breast milk.

\section{Continued breastfeeding at 1 year}

The proportion of children 12-15 months of age who were fed breast milk.

\section{Introduction of solid, semisolid or soft foods}

The proportion of infants 6-8 months of age who received solid, semisolid or soft foods.

\section{Minimum dietary diversity}

The proportion of children 6-23 months of age who received foods from four or more food groups per day. The seven foods groups used for this indicator were grains, roots and tubers, legumes and nuts, dairy products (milk, yoghurt and cheese), flesh foods (meat, fish, poultry and liver or organ meats), eggs, vitamin A-rich fruits and vegetables and other fruits and vegetables.

\section{Children ever breastfed}

The proportion of children who were ever breastfed.

\section{Bottle-feeding}

The proportion of children 0-23 months of age who were fed with a bottle, regardless of whether the infant was breastfed. 


\section{Milk-feeding frequency for non-breastfed children}

Proportion of non-breastfed children 6-23 months of age who received at least two milk feedings per day.

The WHO Anthropometric calculator application (version 3.2.2, January 2011) was used for $z$-score calculations of weight/ age, length/age, weight/length and head circumference/age. Anthropometry defined ${ }^{23}$ as underweight: below -2 standard deviations (SD) from median weight for age of reference population; wasting: below -2 SD from median weight for height of reference population; and stunting: below -2 SD from median height for age of reference population. Feeding practices and nutritional status indicators were reported as median (med) and interquartile range.

\section{Results}

Participants were recruited over a 16-week period from March to June 2009. Forty-seven mother-infant pairs (25 HEU and $22 \mathrm{HU}$ infants) participated in this nutritional substudy (Table 1). Eight (17\%) infants, one HU and seven HEU, were lost to follow-up over the next 12 months on the nutrition substudy.

The HEU children were mainly Xhosa (76\%) and HU were mainly mixed race (77\%). Occupation density and number of young children in the households were similar. Nearly half of the households had running water and ablution facilities inside the house. More HU mothers smoked $(73 \%$ versus $28 \%$ ) and used alcohol (23\% versus $4 \%$ ).

In the HEU group, only one mother initiated breastfeeding and was still breastfeeding at 18 months (Table 2). In the HU group, all mothers initiated breastfeeding with over half starting within an hour of delivery. At 12 and 18 months, $62 \%$ and $52 \%$ of the HU mothers were still breastfeeding. No infant was exclusively breastfeeding at 6 months. In the HEU group, there was $100 \%$ adequate formula milk frequency at

TABLE 1: Sociodemographic characteristics of HIV-exposed uninfected and HIV-unexposed infants at enrolment in nutrition study at 6 months of age.

\begin{tabular}{|c|c|c|c|c|c|c|}
\hline \multirow[t]{2}{*}{ Characteristics } & \multicolumn{3}{|c|}{ HEU $(n=25)$} & \multicolumn{3}{|c|}{ HU $(n=22)$} \\
\hline & $n$ & $\%$ & IQR & $N$ & $\%$ & IQR \\
\hline Males & 7 & 28 & - & 12 & 55 & - \\
\hline Ethnicity: Mixed race people & 6 & 24 & - & 17 & 77 & - \\
\hline Ethnicity: White people & 0 & - & - & 1 & 5 & - \\
\hline Ethnicity: Black people & 19 & 76 & - & 4 & 18 & - \\
\hline Inhabitants per household median & 6 & - & $3-5$ & 4 & - & $4-7$ \\
\hline Children under 13 years median & 2 & - & $1-2.5$ & 2 & - & $1-3$ \\
\hline Number employed in household median & 1 & - & 1 & 1 & - & $1-2$ \\
\hline Running water within house & 11 & 44 & - & 10 & 50 & - \\
\hline Ablution within house & 12 & 48 & - & 10 & 50 & - \\
\hline Mothers using alcohol & 1 & 4 & - & 5 & 23 & - \\
\hline Mothers smoking & 7 & 28 & - & 16 & 73 & - \\
\hline
\end{tabular}

HEU, HIV-exposed uninfected children; HU, HIV-unexposed children; IQR, interquartile range.

TABLE 2: Feeding practices by World Health Organization indicators 19 of HIV-exposed uninfected and HIV-unexposed children.

\begin{tabular}{|c|c|c|c|c|c|}
\hline \multirow[t]{2}{*}{ WHO indicator } & \multirow[t]{2}{*}{ Study visit } & \multicolumn{2}{|c|}{ HEU } & \multicolumn{2}{|c|}{ HU } \\
\hline & & $n$ & $\%$ & $n$ & $\%$ \\
\hline Ever breastfed & - & 1 & 4 & 22 & 100 \\
\hline \multirow[t]{3}{*}{ Early initiation of breastfeeding } & Confirmed & 0 & - & 12 & 55 \\
\hline & Not initiated early & 1 & 100 & 6 & 27 \\
\hline & Unknown & 0 & - & 4 & 18 \\
\hline \multirow[t]{3}{*}{ Continued breastfeeding at } & 6 months & 1 & 4 & 13 & 59 \\
\hline & 12 months & 1 & 5 & 13 & 62 \\
\hline & 18 months & 1 & 6 & 11 & 52 \\
\hline Exclusive breastfeeding at 6 months & - & 0 & - & 0 & - \\
\hline \multirow[t]{3}{*}{ Adequate milk frequency } & 6 months & 24 & 100 & Not applicable & - \\
\hline & 12 months & 16 & 80 & 6 & 100 \\
\hline & 18 months & 15 & 83 & 8 & 80 \\
\hline \multirow[t]{2}{*}{ Bottle-fed } & 12 months & 20 & 95 & 13 & 72 \\
\hline & 18 months & 14 & 93 & 15 & 79 \\
\hline \multirow[t]{3}{*}{ Minimum dietary diversity } & 6 months & 5 & 20 & 10 & 46 \\
\hline & 12 months & 13 & 65 & 10 & 56 \\
\hline & 18 months & 11 & 61 & 14 & 67 \\
\hline \multirow[t]{3}{*}{ Nonnutritional foods $s^{a}$} & 6 months & 8 & 32 & 15 & 68 \\
\hline & 12 months & 12 & 52 & 20 & 100 \\
\hline & 18 months & 18 & 100 & 21 & 100 \\
\hline
\end{tabular}

HEU, HIV-exposed uninfected children; HU, HIV-unexposed children.

HEU: 6 months: $n=25 ; 12$ months: $n=23$; 18 months: $n=18$; HU: 6 months: $n=22 ; 12$ months: $n=21 ; 18$ months: $n=21$.

a, Nonnutritional foods (salty snacks and sugar-containing snacks and drinks). 
TABLE 3: Anthropometry of HIV-exposed uninfected and HIV-unexposed infants.

\begin{tabular}{|c|c|c|c|c|c|}
\hline$z$-score & Months & HEU median & IQR & HU median & IQR \\
\hline \multirow[t]{3}{*}{ Weight/age } & 6 & -0.07 & -0.67 to 0.92 & -0.96 & -1.52 to 0.32 \\
\hline & 12 & 0.04 & -0.61 to 1.15 & -0.39 & -1.24 to -0.18 \\
\hline & 18 & 0.15 & -0.53 to 1.33 & -0.31 & -1.47 to 0.12 \\
\hline \multirow[t]{3}{*}{ Length/age } & 6 & -0.4 & -1.07 to 0.09 & -0.93 & -2.30 to 0.07 \\
\hline & 12 & -0.09 & -0.8 to 0.73 & -0.39 & -1.82 to 0.71 \\
\hline & 18 & -0.29 & -0.72 to 0.64 & -0.94 & -1.64 to 0.36 \\
\hline \multirow[t]{3}{*}{ Weight/length } & 6 & 1.09 & -0.37 to 1.56 & 0.08 & -0.78 to 0.87 \\
\hline & 12 & 0.17 & -0.46 to 1.27 & -0.34 & -1.04 to 0.81 \\
\hline & 18 & 0.61 & -0.33 to 1.21 & -0.27 & -1.02 to 0.62 \\
\hline \multirow[t]{3}{*}{ Head circumference/age } & 6 & 0.53 & 0.02 to 1.07 & -0.32 & -1.05 to 0.15 \\
\hline & 12 & 0.37 & -0.02 to 1.11 & -0.66 & -1.22 to 0.34 \\
\hline & 18 & 0.54 & -0.50 to 1.15 & -0.42 & -0.93 to 0.51 \\
\hline
\end{tabular}

HEU, HIV-exposed uninfected children; HU, HIV-unexposed children; IQR, interquartile range.

TABLE 4: Nutritional indicators of HIV-exposed uninfected and HIV-unexposed infants.

\begin{tabular}{|c|c|c|c|c|c|c|c|c|}
\hline \multirow[t]{2}{*}{ Months } & \multirow{2}{*}{$\begin{array}{l}\text { Study } \\
\text { group }\end{array}$} & \multirow[t]{2}{*}{$n$} & \multicolumn{2}{|c|}{ Underweight } & \multicolumn{2}{|c|}{ Stunted } & \multicolumn{2}{|c|}{ Wasted } \\
\hline & & & $n$ & $\%$ & $n$ & $\%$ & $n$ & $\%$ \\
\hline \multirow[t]{2}{*}{6} & HEU & 25 & 0 & - & 2 & 8 & 0 & - \\
\hline & $\mathrm{HU}$ & 22 & 2 & 9 & 6 & 27 & 1 & 5 \\
\hline \multirow[t]{2}{*}{12} & HEU & 23 & 0 & - & 0 & - & 1 & 4 \\
\hline & $\mathrm{HU}$ & 21 & 3 & 14 & 4 & 19 & 0 & - \\
\hline \multirow[t]{2}{*}{18} & HEU & 18 & 0 & - & 0 & - & 0 & - \\
\hline & HU & 21 & 2 & 10 & 4 & 19 & 0 & - \\
\hline
\end{tabular}

HEU, HIV-exposed uninfected children; HU, HIV-unexposed children.

6 months, dropping to $80 \%$ at 12 and 18 months. The HU group had a similar trend but with a later time decline $(100 \%$ at 12 months and $80 \%$ at 18 months).

No information was available on bottle-feeding at 6 months because of misinterpretation of the survey question. However, all but one HEU infant were assumed to bottlefeed, as only one mother was breastfeeding. Almost all HEU infants were bottle-fed from 12 to 18 months. Amongst the HU infants, $72 \%$ and $79 \%$ were bottle-fed at 12 and 18 months.

At 6 months, $96 \%$ of $\mathrm{HU}$ and $76 \%$ HEU infants had solid, semisolid or soft foods introduced. At 6 months, $46 \%$ of HU and 20\% HEU had minimum dietary diversity. By 12 months, it was $65 \%$ for HEU and $56 \%$ for HU and by 18 months it was $61 \%$ and $67 \%$, respectively, for HEU and HU.

Sixty-eight percent of HU and 32\% of HEU infants were fed nonnutritional foods at 6 months increasing to all $\mathrm{HU}$ and about half the HEU infants at 12 months. By 18 months, all infants were receiving nonnutritional foods.

The HU group had poorer anthropometry (Table 3) and nutritional indicators than the HEU group at 6 and 18 months (Table 4). No HEU infants were underweight at any time point. Amongst the HU, 2 (9\%) were underweight at 6 months, $3(14 \%)$ at 12 months and $2(10 \%)$ at 18 months. Amongst HU, 6 (27\%) were stunted at 6 months, declining to $4(19 \%)$ at 12 and 18 months. One HEU infant was wasted at 12 months and one HU infant was wasted at 6 months.

\section{Discussion}

In this small study, we documented detailed feeding history in HEU predominantly Xhosa infants and HU predominantly mixed race infants. In both groups, adherence to breastfeeding recommendations was low and there was suboptimal dietary diversity. However, there were significant differences between groups in the practices and outcomes.

Breastfeeding occurred in all HU and in one HEU infant(s). The mainly formula-fed HEU infants had a significant decrease in milk frequency after 6 months, coinciding with no access to free formula after this age. We noted a high rate of sugar- and salt-containing snacks given from a young age in both groups. The HU group had poorer anthropometric and poorer nutritional indicators not explained by nutritional factors alone. Alcohol and tobacco use were much higher amongst the HU mothers. All these factors (ethnicity, smoking and alcohol use) may have played a role in the difference in anthropometric and nutritional indicators between the two groups. Because of these confounding factors and small sample size, statistical analyses were not included.

The rate of breastfeeding was extremely low in HEU infants, possibly because free formula milk through public health facilities for the first 6 months of life for all HEU was standard of care at the time. All HU infants were initiated on breastfeeding, whilst the provincial average was $87.1 \%$ in 2003-2004, ${ }^{24}$ suggesting some success of the baby-friendly initiative. ${ }^{25}$ In contrast, the proportion of mothers reporting initiation of breastfeeding within an hour after birth was lower than the provincial figure (55\% versus $69.3 \%)^{24}$ and the $95 \%{ }^{26}$ found in another Western Cape study, whilst other studies reported that few infants were breastfed within 1 hour after birth..$^{27}$ Late initiation is a concern as neonatal mortality may increase markedly with increasing delay in initiating breastfeeding. ${ }^{28}$

In this study, no infant was exclusively breastfed at 6 months. This is lower than the national average of $8.5 \%{ }^{24}$ of infants exclusively breastfed until just under 6 months. It is generally accepted that the proportion of children who are exclusively breastfed until just under 6 months of age is lower than the 
number derived from the indicator of current status at 6 months, ${ }^{22}$ which may explain our finding. South Africa has one of the lowest rates of exclusive breastfeeding in the world..$^{29,30}$ Reasons for this low rate are complex but include longstanding cultural practices, historical lack of promotion of breastfeeding because of high HIV prevalence and the provision of free formula milk through the PMTCT programme. $^{31}$

Continued breastfeeding at 1 year was similar to the national proportion. ${ }^{24}$ Our study does not include data at 20-23 months, the WHO indicator for continued breastfeeding at 2 years. However, over $50 \%$ of $\mathrm{HU}$ infants were still breastfed at 18 months compared with $30.6 \%$ at 2 years nationally. ${ }^{32}$ In contrast, in the developing world, about $86 \%$ of infants 6-11 months were still breastfed, ranging from $92 \%$ and $88 \%$ in Africa and Asia, respectively, to $60 \%$ in Latin America and the Caribbean..$^{30}$ For children 12-23 months of age, the prevalence of continued breastfeeding dropped to about $70 \%$ and $72 \%$ in Africa and Asia, respectively. ${ }^{30}$

Adequate milk frequency for HEU infants decreased significantly from $100 \%$ at 6 months to $80 \%$ at 12 and 18 months. This may have been due to the provision of free formula milk to all HEU infants for the first 6 months of life at the time of the study. Poorer caregivers may struggle to pay for formula milk thereafter ${ }^{26}$ or may have chosen to spend their money on other forms of nutrition. The current policy puts more emphasis on social circumstances (replacement feeding only when it is acceptable, feasible, affordable, sustainable and safe) and should help to prevent inadequate milk frequency for HEU infants in future.

The proportion of infants bottle-fed in the study exceeded national figures; $72 \%$ of HU infants at 12 months compared to $40 \%$ nationally at $12-15$ months. Furthermore, $79 \%$ of this group were bottle-fed at 18 months compared to $27 \%$ at $16-19$ months nationally. ${ }^{32}$ Information on bottle-feeding is useful because of the potential interference of bottle-feeding with optimal breastfeeding and the association between bottle-feeding and increased diarrhoeal disease morbidity and mortality. ${ }^{22}$

Early introduction of complementary food is common in many developing countries ${ }^{33,34}$ and in this study. The lower percentage in the HEU group might reflect nutrition counselling input from the clinic staff as these mothers had monthly clinic visits for formula supply in addition to immunisation visits.

Dietary diversity was inappropriate during the first few months after weaning. Dietary diversity is essential as inadequate complementary feeding at 6 months of age is associated with impaired growth and increased stunting during the next 12 months. ${ }^{35}$ Children aged 6-24 months are at the greatest risk from poor feeding practices. ${ }^{36,37}$ Minimum dietary diversity was better in the HU group compared to HEU at 6 months, poorer at 12 months, and almost equal at 18 months. The later introduction of complementary food in the HEU group might explain the poorer dietary diversity at 6 months.

All the HU were given snacks and/or drinks containing sugar and salt at 12 months and HEU infants by 18 months. The widespread use of such goods at a young age may increase risk of elevated blood pressure ${ }^{38}$ and obesity later in life. ${ }^{39}$ High-sugar foods displace whole foods (e.g. soft drinks displace milk and juice consumption) and contribute to nutritional deficiencies, adding empty kilojoules ${ }^{40}$ as they reduce dietary diversity. Furthermore, sugar contributes to dental caries. ${ }^{41}$ The Road to Health booklet already contains basic Health Promoting Messages. Health professionals at primary care should highlight this advice to mothers.

The HU group had poorer nutritional and anthropometric indicators than the HEU group, despite the higher infectious morbidity already described in the HEU group. ${ }^{21}$ The higher infectious morbidity by 12 months may be attributed to deficient immunity rather than their diet. In a recent study of premature infants from the same demographic area, the HEU infants also had better anthropometric indicators than the HU group..$^{42}$ No difference in 2-year rates of adverse health outcomes between early-weaned breastfed and formula-fed children born to HIV-infected mothers has been reported..$^{43}$ A study from Latin America found the association between stunting and feeding practices generally weaker and less consistent during the first year of life, increasing gradually with age. ${ }^{44}$ Stunting was more prevalent in both groups studied as observed in the national food consumption survey in 1999 where $10.3 \%$ children 1-9 years were underweight and $21.6 \%$ were stunted. ${ }^{45}$

A much higher proportion of the mothers in the HU group (23\% versus $4 \%$ ) reported alcohol use. Excessive alcohol consumption remains a serious social and public health problem in the Western Cape. The prevalence of risky drinking (more than two drinks per day for women) is higher in the Western Cape Province than in all the other provinces (9\% compared with $\leq 5 \%$ ), with mixed race women having higher levels than other communities (12.6\% compared with $\leq 2 \%) .{ }^{30}$ Evidence regarding the negative effects of heavy drinking in pregnancy is well established. Even low levels of maternal alcohol consumption have a negative association with foetal growth. ${ }^{46}$

In our study, $73 \%$ of the mothers of HU infants compared to $28 \%$ of the HEU group reported smoking. The Western Cape Province has the highest prevalence of smoking of all the provinces: $44.7 \%$ of men and $27 \%$ of women including a large proportion of pregnant women. ${ }^{47}$ Smoking reduces weight, length and head circumference at birth ${ }^{48}$ and during the first 2 years of life, independent of several confounding factors. ${ }^{49}$ Ethnicity and the habits of the mother (smoking and alcohol use) during pregnancy and breastfeeding likely affected the difference in anthropometry and nutrition indicators between the two groups. 


\section{Limitations}

This study had a small sample size with various confounding factors in both groups. Interviewer standardisation and guidelines for use of questionnaires were not strictly controlled and some misinterpretation of the questionnaire is possible. In our opinion, even though the data are from 2009 , it remains relevant to feeding practices and social issues impacting on healthy growth in the current social and economic climate.

\section{Conclusion}

The study found disturbing information regarding feeding patterns and growth in two different cultural groups with similar economic surroundings. Infants in both groups received nonnutritional foods with high sugar and salt content, emphasising a general lack of nutritional awareness. More education and more counselling are imperative. Further research is needed to understand reasons for the poorer nutritional and anthropometric indicators in the HU group. The role of smoking and alcohol use during pregnancy and breastfeeding and other potential confounders require further investigation.

\section{Acknowledgements}

The authors thank students of the Hochschule Niederrhein, University of Applied Sciences, Faculty of Food, Nutrition and Hospitality Sciences, Germany, who developed the questionnaire. The authors acknowledge the dedication shown by Sister S. Sylvester who helped with administering of questionnaires, performed anthropometric measurements and co-ordinated follow-up visits and the participants and their mothers.

\section{Competing interests}

The authors declare that they have no financial or personal relationships which may have inappropriately influenced them in writing this article.

\section{Authors' contributions}

M.E.R. was the primary author of the article. M.C. and M.F.C. made significant conceptual contributions. M.M.E. was the study leader and responsible for the project protocol and gave valuable comments.

\section{References}

1. De Zoysa I, Rea M, Martines J. Why promote breastfeeding in diarrhoeal disease control programmes? Health Policy Plan. 1991;6(4):371-379. http://dx.doi: 10.1093/heapol/6.4.371

2. Cunningham AS, Jelliffe DB, Jelliffe EF. Breast-feeding and health in the 1980 's: A global epidemiologic review. J Pediatr. 1991;118:659-666. http://dx.doi. org/10.1016/s0022-3476(05)80023-X

3. Newman J. How breast milk protects newborns. Sci Am. 1995;273:76-79. http:// dx.doi.org/10.1038/scientificamerican1295-76

4. Cohen RJ, Brown KH, Dewey KG, Canahuati J, Landa Rivera L. Effects of age of introduction of complementary foods on infant breast milk intake, total energy intake, and growth: A randomised intervention study in Honduras. Lancet. 1994;344(8918):288-293. http://dx.doi:10.1016/S0140-6736(94)91337-4
5. Administrative Committee on Coordination, Subcommittee on Nutrition. Breastfeeding and complementary feeding. In: Fourth report on the world nutrition situation. Gena: Administrative Committee on Coordination, Subcommittee on Nutrition: in collaboration with International Food Policy Research Institute, 2000: pp. 47-55. http://dx.doi.org/10.1016/s0169 5150(00)00124-9

6. World Health Organization/Department of Nutrition for Health and Development, Department of Child and Adolescent Health and Development. Report of an expert consultation: The optimal duration of exclusive breastfeeding. Geneva: World Health Organization, 2002.

7. Kramer MS, Kakuma R. Optimal duration of exclusive breastfeeding. Cochrane Database Syst Rev. 2012;8:CD003517. http://dx.doi.org/10.1002/14651858. CD003517.pub2

8. Victora CG, Smith PG, Vaughan JP, et al. Evidence for protection by breast-feeding against infant deaths from infectious diseases in Brazil. Lancet. 1987;2(8554): 319-322. http://dx.doi.org/10.1016/s0140-6736(87)90902-0

9. Brown KH, Black RE, Lopez de Romaña G, Creed de Kanashiro H. Infant feeding practices and their relationship with diarrhoeal and other diseases in Huascar (Lima), Peru. Pediatrics. 1989;83:31-40.

10. Arifeen S, Black RE, Antelman G, Baqui A, Caulfield L, Becker S. Exclusive breastfeeding reduces acute respiratory infection and diarrhea deaths among infants in Dhaka slums. Pediatrics. 2001;108(4):E67. http://dx.doi.org/10.1542/ peds.108.4.e67

11. World Health Organization/UNAIDS/UNICEF/United Nations Population Fund. HIV and infant feeding: Guidelines for decision makers. Geneva: World Health Organization, 2003 [cited 2014 July 23]. Available from: http://www.who.int/iris/ handle/10665/43864

12. Pronczuk J, Moy G, Vallenas C. Breast milk: An optimal food. Environ Health Perspect. 2004;112(13):A722-723. http://dx.doi.org/10.1289/ehp.112-a722

13. Department of Health (South Africa). National consolidated guidelines, April 2015. Pretoria, 2015 [cited 2015 Oct 03]. Available from: http://www.hst.org.za/ sites/default/files/268965647-National-Consolidated-Guidelines-for-PMTCT-andsites/default/files/268965647-National-Consolidated-Guidelines-for-P
the-Management-of-HIV-in-Children-Adolescents-and-Adults.pdf3

14. UNICEF. Programming guide - infant and young child feeding - June 2012. New York; UNICEF, 2012 [cited 2014 July 23]. Available from: http://www.unicef.org/ nutrition/index_breastfeeding.html

15. Martorell R, Khan LK, Schroeder DG. Reversibility of stunting: Epidemiological findings in children from developing countries. Eur J Clin Nutr. 1994;48:S45-S57.

16. Adair LS, Guilkey DK. Age-specific determinants of stunting in Filipino children. J Nutr. 1997;127:314-320.

17. Allen LH. Nutritional influences on linear growth: A general review. Eur J Clin Nutr. 1994;48:S75-S89.

18. Bloss E, Wainaina F, Bailey RC. Prevalence and predictors of underweight, stunting and wasting among children aged 5 and under in western Kenya. J Trop Pediatr. 2004;50(5):260-270. http://dx.doi.org/10.1093/tropej/50.5.260

19. Department of Health (South Africa). Clinical guidelines: PMTCT (prevention of mother-to child transmission). Pretoria, 2010 [cited 2015 Feb 27]. Available from: http://www.fidssa.co.za/images/PMTCT_Guidelines.pdf

20. Reikie BA, Naidoo S, Ruck CE, et al. Antibody responses to vaccination among South African HIV-exposed and unexposed uninfected infants over the first two years of life. Clin Vaccine Immunol. 2013;20(1):33-38. http://dx.doi.org/10.1128/ cvi.00557-12

21. Slogrove AL, Cotton MF, Esser MM. Severe infections in HIV-exposed uninfected infants: Clinical evidence of immunodeficiency. J Trop Pediatr. 2010;56(2):75-81. http://dx.doi.org/10.1093/tropej/fmp057

22. UNICEF/WHO. Indicators for assessing infant and young child feeding practices Part 1. Definitions. Geneva: World Health Organization, 2008.

23. UNICEF. Definitions - Nutrition - Definitions of the indicators. 2014 [cited 2014 July 23]. Available from: http://www.unicef.org/infobycountry/stats_popup2.html

24. World Health Organization - Nutrition- The WHO Global Data Bank on Infant and Young Child Feeding. Geneva: World Health Organization, 2010 [cited 2014 July 23]. Available from: http://www.who.int/nutrition/databases/ infantfeeding/en/

25. World Health Organization - Nutrition - Baby-friendly hospital initiative. Geneva: World Health Organization, 2009 [cited 2015 Feb 27]. Available from: http://www. who.int/nutrition/publications/infantfeeding/bfhi_trainingcourse/en/

26. Goosen C, McLachlan MH, Schübl C. Infant feeding practices during the first 6 months of life in a low-income area of the Western Cape Province. S Afr J Child Health. 2014;8(2):50-54. http://dx.doi.10.7196/SAJCH.675

27. Bland RM1, Rollins NC, Coutsoudis A, Coovadia HM. Child health group. Breastfeeding practices in an area of HIV prevalence in rural South Africa. Acta Paediatr. 2002;91(6):704-711 http://dx.doi.10.1111/j.1651-2227.2002.tb03306.x

28. Edmond KM, Zandoh C, Quigley MA, Amenga-Etego S, Owusu-Agyei S, Kirkwood BR. Delayed breastfeeding initiation increases risk of neonatal mortality Pediatrics. 2006;117(3):e380-386. http://dx.doi.org/10.1542/peds.2005-1496

29. Tylleskär T, Jackson D, Meda N, et al. Exclusive breastfeeding promotion by peer counsellors in sub-Saharan Africa (PROMISE-EBF): A cluster-randomised trial. Lancet. 2011;378:420-427. http://dx.doi:10.1016/S0140-6736(11)60738-1

30. Department of Health, Medical Research Council, OrcMacro. South Africa demographic and health survey 2003. Pretoria: Department of Health, 2007 [cited 2014 July 23]. Available from: http://www.mrc.ac.za/bod/sadhs.htm

31. Malek A. An evaluation of the protein energy malnutrition (PEM) food scheme for children aged 0 to 5 years in Mitchell's Plain, Western Cape, South Africa. S Afr J Nutr. 1997;87(9):1242. 
32. Lauer JA, Betrán AP, Victora CG, De Onís M, Barros AJ. Breastfeeding patterns and exposure to suboptimal breastfeeding among children in developing countries: Review and analysis of nationally representative surveys. BMC Med. 2004;2:26. http://dx.doi.org/10.1186/1741-7015-2-26

33. World Health Organization - Nutrition - Complementary feeding of young children in developing countries. A review of current scientific knowledge. Geneva: World Health Organization, 1998 [cited 2014 July 23]. Available from: http://www.who.int/nutrition/publications/infantfeeding/WHO_NUT_98.1/en/

34. Faber M, Benadé AJ. Nutritional status and dietary practices of 4-24-month-old children from a rural South African community. Public Health Nutr. 1999;2(2): 179-185. http://dx.doi.org/10.1017/s1368980099000233

35. Becquet R, Leroy V, Ekouevi DK, et al. Complementary feeding adequacy in relation to nutritional status among early weaned breastfed children who are born to HIV infected mothers: ANRS 1201/1202 Ditrame plus, Abidjan, Côte d'Ivoire. Paediatrics. 2006;117(4):e701-e710. http://dx.doi.10.1542/peds.2005-1911

36. Hotz C, Gibson RS. Complementary feeding practices and dietary intakes from complementary foods among weanlings in rural Malawi. Eur J Clin Nutr. 2001;55(10):841-849. http://dx.doi.org/10.1038/sj.ejcn.1601239

37. World Health Organization - Nutrition - Iron deficiency anaemia: Assessment, prevention and control. A guide for programme managers. Geneva: World Health Organization, 2001 [cited 23 July 2014]. Available from: http://www.who.int/ nutrition/publications/micronutrients/anaemia_iron_deficiency/WHO_NHD_ 01.3/en/

38. He FJ, Mac Gregor GA. Importance of salt in determining blood pressure in children meta-analysis of controlled trials. Hypertension. 2006;48(5):861-869. http://dx.doi.org/10.1161/01.hyp.0000245672.27270.4a

39. Weijs PJ, Kool LM, Van Baar NM, Van der Zee SC. High beverage sugar as well as high animal protein intake at infancy may increase overweight risk at 8 years: A prospective longitudinal pilot study. Nutr J. 2011;10:95 http://dx.doi.10.1186/ 1475-2891-10-95

40. Howard BV, Wylie-Rosett J. AHA scientific statement sugar and cardiovascular disease. A statement for healthcare professionals from the Committee on disease. A statement for healthcare professionals from the Committee on American Heart Association. Circulation. 2002;106:523-527. http://dx.doi.org/ 10.1161/01.cir.0000019552.77778.04
41. Burt BA, Eklund SA, Morgan KJ, et al. The effects of sugars intake and frequency of ingestion on dental caries increment in a three-year longitudinal study. $J$ Dent Res. 1988;67(11):1422-1429. http://dx.doi.org/10.1177/002203458806 70111201

42. Van Niekerk E, Kirsten GF, Nel DG, Blaauw R. Probiotics, feeding rolerance and growth: A comparison between HIV-exposed and unexposed very low birth weight infants. Nutrition. 2014;30(6):645-653. http://dx.doi.org/10.1016/j. nut.2013.10.024

43. Becquet R, Bequet L, Ekouevi DK, et al. Two-year morbidity-mortality and alternatives to prolonged breast-feeding among children born to HIV-infected mothers in Cote d'Ivoire. PLoS Med. 2007;4(1):e17. http://dx.doi.org/10.1371/ journal.pmed.0040017

44. International Food Policy research Institute. Food onsumption and Nutrition Division - Creating a child feeding index using the demographic and health surveys: An example from Latin America. Washington, DC: IFPRI, 2002 [cited 2014 July 23]. Available from: http://www.ifpri.org/sites/default/files/publications/ fcndp130.pdf

45. Labadarios D, Steyn NP, Maunder E, et al. The National Food Consumption Survey (NFCS) - Children aged 1-9 years, South Africa, 1999. Public Health Nutr. 2005;8(5):533-543. http://dx.doi.org/10.1079/PHN2005816

46. Nykjaer C, Alwan NA, Greenwood DC, et al. Maternal alcohol intake prior to and during pregnancy and risk of adverse birth outcomes: Evidence from a British cohort. J Epidemiol Community Health. 2014;68(6):542-549. http://dx. doi:10.1136/jech-2013-202934

47. Chopra M, Steyn N, Lambert V. Western Cape Burden of Disease Reduction Project: Final report 2007 (Volume 6) - Cardiovascular diseases. Cape Town: Western Cape Department of Health, 2011 [cited 2014 July 23]. Available from: http://www.westerncape.gov.za/general-publication/wellness-summit-2011 kelvin-gr

48. Zaren B, Lindmark G, Gebre-Medhin M. Maternal smoking and body composition of the newborn. Acta Paediatr. 1996;85(2):213-219. http://dx.doi.org/10.1111/ j.1651-2227.1996.tb13995.x

49. Kanellopoulos TA,Varvarigou AA, Karatza AA, Beratis NG. Course of growth during the first 6 years in children exposed in utero to tobacco smoke. Eur J Pediatr. 2007;166(7):685-692. http://dx.doi.org/10.1007/s00431-006-0308-8 


\section{Appendix 1}

Pilot study of innate immune abnormalities in HIV-exposed uninfected infants.

Project number: 08/10/289

\section{Questionnaire for assessing infant and child feeding practices}

\begin{tabular}{|lll}
\hline Date of interview: & & \\
Study number: & (dd/mm/yyyy) \\
Person interviewed: & $\square$ Primary caregiver & $\square$ Other \\
\hline
\end{tabular}

Number of persons in household:

Number of adults with an income from work (formal/informal):

Social grant attributing to household income:

$\begin{array}{llll}\square \text { No Grant } & \square \text { Child } & \square \text { Disability } & \square \text { Tb/HIV Grant }\end{array} \quad \square$ Pension $\quad \square$ Other

\section{Questionnaire Part I}

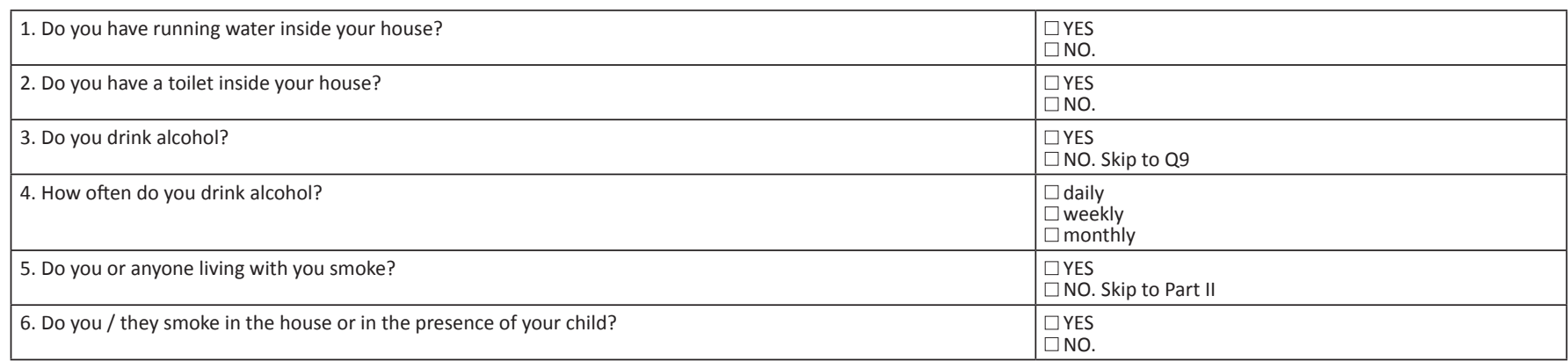

\section{Questionnaire Part II}

\begin{tabular}{|c|c|c|}
\hline Question & \multicolumn{2}{|l|}{ Response } \\
\hline 1. Has (NAME) ever been breastfed? (including milk expressed or from a wet nurse) & \multicolumn{2}{|l|}{$\begin{array}{l}\square \text { YES. Continue below. } \\
\square \text { NO. Skip to Q4. } \\
\square \text { Don't know. Skip to Q41 st at5mo }\end{array}$} \\
\hline 2. How long after birth was (NAME) put to the breast? & \multicolumn{2}{|l|}{$\begin{array}{l}\square \text { Within one hour } \\
\square \text { Not within one hour } \\
\square \text { Don't know }\end{array}$} \\
\hline 3. Did (NAME) have breast milk yesterday during the day or night? & \multicolumn{2}{|l|}{$\begin{array}{l}\square \text { YES } \\
\square \text { NO } \\
\square \text { Don't know }\end{array}$} \\
\hline \multicolumn{3}{|l|}{ 4. Was (NAME) given any of the following yesterday during the day or night: } \\
\hline a) Vitamin drops, medicine, gripe water or the sugar-salt solution & \multicolumn{2}{|l|}{$\begin{array}{l}\square \text { YES } \\
\square \text { NO } \\
\square \text { Don't know }\end{array}$} \\
\hline b) Plain water, clear soup, tea without milk & \multicolumn{2}{|l|}{\begin{tabular}{|l}
$\square$ YES \\
$\square$ NO \\
$\square$ Don't know \\
\end{tabular}} \\
\hline c) Juice & \multicolumn{2}{|l|}{$\begin{array}{l}\square \text { YES } \\
\square \text { NO } \\
\square \text { Don't know } \\
\end{array}$} \\
\hline d) Thin porridge & \multicolumn{2}{|l|}{$\begin{array}{l}\square \text { YES } \\
\square \text { NO } \\
\square \text { Don't know }\end{array}$} \\
\hline e) Infant formula such as Pelargon, Nan, Infacare, S26, Similac & $\begin{array}{l}\square \text { YES } \\
\square \text { NO } \\
\square \text { Don't know }\end{array}$ & $\begin{array}{l}\text { How many times? } \\
\square\end{array}$ \\
\hline f) Animal milk, fresh powdered or tinned & $\begin{array}{l}\square \text { YES } \\
\square \text { NO } \\
\square \text { Don't know }\end{array}$ & $\square$ \\
\hline
\end{tabular}




\begin{tabular}{|l|l|l|}
\hline g) Yogurt & $\begin{array}{l}\square \text { YES } \\
\square \text { NO } \\
\square \text { Don't know }\end{array}$ \\
\hline h) Any solid, semisolid or soft foods other than liquids & $\begin{array}{l}\square \text { YES } \\
\square \text { NO } \\
\square \text { Don't know }\end{array}$ \\
\hline 5. Did (NAME) drink anything from a bottle with a teat yesterday during the day or night? & $\square$ YES \\
& $\begin{array}{l}\text { NO } \\
\square \text { Don't know }\end{array}$ \\
\hline 6. Do you pre-chew food for your child? & $\square$ YES \\
$\square$ NO
\end{tabular}

\begin{tabular}{|c|c|c|c|}
\hline Question & \multicolumn{3}{|c|}{ Response } \\
\hline \multicolumn{4}{|c|}{ 7. Please describe everything (NAME) ate yesterday during the day and night in and outside the home. } \\
\hline a) Bread, porridge, cereal, rice, pasta, savoury biscuits, barley, wheat or samp. & $\square$ YES & $\square \mathrm{NO}$ & $\square \mathrm{DK}$ \\
\hline b) Carrots, pumpkin, butternut or sweet potatoes that is yellow inside. & $\square$ YES & $\square$ NO & $\square \mathrm{DK}$ \\
\hline c) Potatoes, sweet potatoes that is white inside. & $\square$ YES & $\square$ NO & $\square \mathrm{DK}$ \\
\hline d) Dark green leafy vegetables like lettuce, spinach or broccoli. & $\square$ YES & $\square$ NO & $\square \mathrm{DK}$ \\
\hline e) Paw-paw, apricots, mango, yellow peach or watermelon (orange in colour). & $\square$ YES & $\square$ NO & $\square \mathrm{DK}$ \\
\hline f) Any other fruits and vegetables. & $\square$ YES & $\square$ NO & $\square \mathrm{DK}$ \\
\hline g) Any food made from dried peas, beans, lentils, nuts and seeds or peanut butter. & $\square$ YES & $\square$ NO & $\square \mathrm{DK}$ \\
\hline h) Yogurt, cheese, custard, ice-cream (dairy) or other milk products. & $\square$ YES & $\square$ NO & $\square \mathrm{DK}$ \\
\hline i) Meat, fish, chicken or liver/organ meats & $\square$ YES & $\square$ NO & $\square \mathrm{DK}$ \\
\hline j) Eggs & $\square$ YES & $\square$ NO & $\square \mathrm{DK}$ \\
\hline k) Sweetened drinks: Coke, Fanta, Oros & $\square$ YES & $\square$ NO & $\square \mathrm{DK}$ \\
\hline l) Chocolate & $\square$ YES & $\square \mathrm{NO}$ & $\square \mathrm{DK}$ \\
\hline m) Sweet biscuits: (e.g. Marie, Lemon creams) or cake & $\square$ YES & $\square$ NO & $\square \mathrm{DK}$ \\
\hline n) Sweets & $\square$ YES & $\square \mathrm{NO}$ & $\square \mathrm{DK}$ \\
\hline o) Honey, jam, sugar & $\square$ YES & $\square$ NO & $\square \mathrm{DK}$ \\
\hline p) Chips (crisps) & $\square$ YES & $\square$ NO & $\square \mathrm{DK}$ \\
\hline 8. Did (NAME) receive any baby cereal like Nestum, Cerelac, Purity. & $\square$ YES & $\square \mathrm{NO}$ & $\square \mathrm{DK}$ \\
\hline
\end{tabular}

(Would you like any further information on feeding your baby?)

$\square$ YES

$\square$ NO

Signature:

Date: 